\title{
Urea hydrolysis and recovery of nitrogen and phosphorous as MAP from stale human urine
}

\author{
LIU Zhigang ${ }^{1}$, ZHAO Qingliang ${ }^{1, *}$, WANG Kun ${ }^{1}$, LEE Duujong ${ }^{2}$, QIU Wei ${ }^{1}$, WANG Jianfang ${ }^{1}$ \\ 1. State Key Lab of Urban Water Resource and Environment, School of Municipal and Environmental Engineering, Harbin Institute of Technology, \\ Harbin 150090, China. E-mail: lzg-0532@163.com \\ 2. Department of Chemical Engineering, "National” Taiwan University, Taipei, Taiwan 10617, China
}

Received 18 September 2007; revised 1 November 2007; accepted 12 November 2007

\begin{abstract}
Laboratory-scale tests for magnesium ammonium phosphate (MAP) precipitation following urea hydrolysis of human urine were conducted using orthogonal experiment design. The effects of initial $\mathrm{pH}$, temperature and the volumetric ratios of stale urine to fresh urine, on urea hydrolysis in urine were studied to determine the final hydrolysis time to recover most nitrogen from separated human urine by MAP. With a volumetric ratio of stale to fresh urine $>10 \%$ and at temperature $\geqslant 20^{\circ} \mathrm{C}$, urea hydrolysis could be completed in two days. Alkaline $\mathrm{pH}$ inhibited urea hydrolysis progress. The final $\mathrm{pH}$ values were all around 9.0 following urine hydrolysis, while the suspension $\mathrm{pH}$ might act as an indicator to detect the start and extent of urea hydrolysis. Over $95 \%$ of ammonium nitrogen and over $85 \%$ of phosphorus from hydrolyzed urine as MAP precipitate were obtained using $\mathrm{MgCl}_{2} \cdot 6 \mathrm{H}_{2} \mathrm{O}$ and $\mathrm{Na}_{2} \mathrm{HPO}_{4} \cdot 12 \mathrm{H}_{2} \mathrm{O}$ as precipitation agents at $\mathrm{pH}$ 8.5, molar ratio of $\mathrm{Mg}^{2+}: \mathrm{NH}_{4}{ }^{+}-\mathrm{N}: \mathrm{PO}_{4}{ }^{3-}-\mathrm{P}$ at (1.2-1.3):1:1, mixing speed of $120 \mathrm{r} / \mathrm{min}$, and precipitation time and reaction time of $3 \mathrm{~h}$ and $15 \mathrm{~min}$, respectively. The precipitate has a structure resembling pure MAP crystal.
\end{abstract}

Key words: urea hydrolysis; human urine; magnesium ammonium phosphate (MAP); ammonium-nitrogen $\left(\mathrm{NH}_{4}{ }^{+}-\mathrm{N}\right)$; phosphorus

\section{Introduction}

Nutrient removal from wastewater has gained increasing attention in wastewater treatment plants owing to the strict discharge standards to receiving waters and demand of recycling nutrients for the replenishing depleting resources such as phosphorous. The concentrations of nitrogen and phosphorous in domestic wastewater are generally low and the energy demand of nutrient recovery processes is typically high; hence, the currently applied treatment technologies aim at removing $\mathrm{N}$ or $\mathrm{P}$ without much recovery.

Human urine comprises higher concentrations of sodium chloride, urea, phosphate and potassium, and trace levels of calcium, sulfate and magnesium (Larsen and Gujer, 1996). The $\mathrm{pH}$ value of fresh urine ranges 5.66.8 (Fittschen and Hahn, 1998). Human urine contributes less than $1 \%$ volume of municipal wastewater quantity, but contributes $80 \%$ of N, $50 \%$ of $\mathrm{P}$, and $90 \%$ of $\mathrm{K}$ in municipal wastewater (Larsen et al., 2001). Moreover, since the specific energy consumption rates are high for nutrient removal $\left(45 \times 10^{6} \mathrm{~J} / \mathrm{kgN}\right.$ and $49 \times 10^{6} \mathrm{~J} / \mathrm{kgP}$ ) (Maurer et al., 2003), and source-separation of urine could significantly improve effluent quality and reduce energy, as well as investment costs of the receiving wastewater treatment plants (WWTPs) (Wilsenach and Van Loosdrecht, 2003, 2004),

* Corresponding author.

E-mail: zhq11962@yahoo.com.cn; qlzhao@hit.edu.cn. the collected human urine itself presents a concentrated source of nutrients for recovery at low energy demand. In addition, the source-separated human urine prevents its incorporated heavy metals and certain micro-pollutants, such as pharmaceutics and hormones to "pollute" the main stream of municipal wastewater (Jönsson et al., 1997; Larsen and Udert, 1999; Pronk et al., 2006). Thus urine source-separation was regarded beneficial to wastewater treatment practice and nutrient recovery, although numerous technical drawbacks existed to date (Lind et al., 2000; Pahl-Wosti et al., 2003; Udert et al., 2003a; Ban and Dave, 2004). The use of "NoMix" toilets is an example for implementing urine source-separation concept in Sweden (Hanæus et al., 1997).

The source-separated urine needs treatments or final disposal options, such as recovery of nitrogen and phosphorus through struvite crystallization and adsorption (Lind et al., 2000; Ban and Dave, 2004), autotrophic denitrification by ANAMMOX bacteria (Udert et al., 2003b), removal of micro-pollutants by nanofiltration (Pronk et al., 2006), direct utilization in urban agriculture (Kirchmann and Pettersson, 1995), volume reduction and concentration by freezing (Lind et al., 2001), storage by acidification (Hellström et al., 1999), and ammonia stripping by air (Basakcilardan-Kabakci et al., 2007). The magnesium ammonium phosphate (MAP, mineralogically as struvite) crystallization and precipitation process can recover 
ammonium nitrogen and phosphorous simultaneously to produce MAP as slow-release fertilizer ( $\mathrm{Li}$ and Zhao, 2003) through the following chemical reaction:

$$
\begin{array}{r}
\mathrm{Mg}^{2+}+\mathrm{NH}_{4}^{+}+\mathrm{PO}_{4}^{3-}+6 \mathrm{H}_{2} \mathrm{O} \underset{\left(\mathrm{p} K_{\mathrm{s}}=12.6,25^{\circ} \mathrm{C}\right)}{\mathrm{MgNH}} \mathrm{PO}_{4} \cdot 6 \mathrm{H}_{2} \mathrm{O} \downarrow
\end{array}
$$

Urea should be completely hydrolyzed to $\mathrm{NH}_{4}{ }^{+}$before the precipitation reaction in Reaction (1) can be accomplished. Urease from eucaryotic and procaryotic organisms can hydrolyze urea as follows (Mobley and Hausinger, 1989):

$$
\mathrm{NH}_{2}(\mathrm{CO}) \mathrm{NH}_{2}+2 \mathrm{H}_{2} \mathrm{O} \longrightarrow \mathrm{NH}_{4}^{+}+\mathrm{HCO}_{3}^{-}+\mathrm{NH}_{3}
$$

obviously in Reaction (2), $\mathrm{pH}, \mathrm{NH}_{4}{ }^{+}-\mathrm{N}$ and bicarbonate concentrations increase with urea hydrolysis, leading to changes in $\mathrm{PO}_{4}{ }^{3-}-\mathrm{P}$ concentration following hydrolysis of urea (Kirchmann and Pettersson, 1995; Fittschen and Hahn, 1998; Udert et al., 2003a). Udert et al. (2003a) reported that urea could be completely hydrolyzed in the collection tank in one day if urease was added with sufficient mixing and the hydrolysis temperature was maintained at $25^{\circ} \mathrm{C}$. However, existing related works in the published report did not comprehensively reveal the relationship between hydrolysis time for urine under different initial $\mathrm{pH}$, temperatures, and volumetric ratios of urine (Udert et al., 2003a; Kabdaşli et al., 2006) and the optimal operational conditions for the subsequent MAP process (Lind et al., 2000; Li and Zhao, 2003; Ban and Dave, 2004). The objective of this study was to determine the final hydrolysis times of the separated urine at different initial conditions and to provide the optimal operational conditions for the subsequent MAP process with the aid of orthogonal experiment.

\section{Materials and methods}

\subsection{Urine samples}

The human urines were collected using cleaned plastic barrels from 5-8 healthy males aged between 25 and 34 (the fresh urine). Two fresh urine samples $(\mathrm{S} \# 1, \mathrm{~S} \# 2)$ were tested in hydrolysis experiments. The initial $\mathrm{pH}, \mathrm{NH}_{4}{ }^{+}-\mathrm{N}$ and $\mathrm{PO}_{4}{ }^{3-}-\mathrm{P}$ concentrations for $\mathrm{S} \# 1$ were $6.71,755$, and $171 \mathrm{mg} / \mathrm{L}$, and for $\mathrm{S} \# 2$ were 6.78, 624, and $161 \mathrm{mg} / \mathrm{L}$, respectively. The completely hydrolyzed urine was named as the stale urine (SU). The $\mathrm{SU}$ with respective $\mathrm{pH}, \mathrm{NH}_{4}{ }^{+}-$ $\mathrm{N}$ and $\mathrm{PO}_{4}{ }^{3-}-\mathrm{P}$ concentrations of 9.35, 7,220, and 206 $\mathrm{mg} / \mathrm{L}$ was tested in the MAP precipitation experiments.

\subsection{Urea hydrolysis experiments}

The $500 \mathrm{ml}$ urine sample (S\#1) was placed equally in five beakers. One beaker filled with fresh urine with no added chemicals was used as the control. The $\mathrm{pH}$ values of filled urine in the remaining four beakers were adjusted to 8-11 using $10 \mathrm{~mol} / \mathrm{L} \mathrm{NaOH}$. Then the beakers were placed steadily to simulate the conditions in urine collecting tank at temperature of $20-22^{\circ} \mathrm{C}$. The supernatants were collect- ed to measure the ammonium nitrogen concentrations and $\mathrm{pH}$ values at $12 \mathrm{~h}$ intervals.

The urine following $15 \mathrm{~d}$ test had been completely hydrolyzed and was the SU samples herein. Another batch of samples was prepared by mixing fresh (S\#2) and the SU samples at different volumetric ratios (Table 1). The mixed samples were placed in $500 \mathrm{ml}$ glass covered bottles, standing still at $18-20^{\circ} \mathrm{C}$ with regular supernatant sample collection. Part of the mixed samples at volumetric ratio of $10 \%$ was tested at $2.5,10,15,20,25$, and $30^{\circ} \mathrm{C}$, respectively.

Table 1 Volumetric ratio of stale urine (SU) to fresh urine (S\#2) in urea hydrolysis experiment

\begin{tabular}{llllll}
\hline Item & \multicolumn{5}{c}{ SU } \\
\cline { 2 - 6 } & 0 & $5 \%$ & $10 \%$ & $15 \%$ & $20 \%$ \\
\hline Stale urine volume $(\mathrm{ml})$ & 0 & 25 & 50 & 75 & 100 \\
S\#2 volume (ml) & 500 & 475 & 450 & 425 & 400 \\
Total volume (ml) & 500 & 500 & 500 & 500 & 500 \\
Initial pH & 6.78 & 8.49 & 8.84 & 8.93 & 9.01 \\
$\mathrm{NH}_{4}{ }^{+}-\mathrm{N} \mathrm{concen}-$ & 624 & 1,025 & 1,373 & 1,697 & 2,027 \\
$\quad$ tration (mg/L) & & & & & \\
\hline
\end{tabular}

\subsection{MAP precipitation experiments}

The MAP precipitation tests were carried out in $1,000 \mathrm{ml}$ beakers with analytical grade $\mathrm{MgCl}_{2} \cdot 6 \mathrm{H}_{2} \mathrm{O}$ and $\mathrm{Na}_{2} \mathrm{HPO}_{4} \cdot 12 \mathrm{H}_{2} \mathrm{O}$ as precipitation agents. $10 \mathrm{~mol} / \mathrm{L} \mathrm{NaOH}$ solution was used to adjust $\mathrm{pH}$. The $\mathrm{pH}, \mathrm{NH}_{4}{ }^{+}-\mathrm{N}$ and $\mathrm{PO}_{4}{ }^{3-}$-P of supernatants collected following MAP precipitation tests was conducted using $\mathrm{L}_{16}\left(4^{4} \times 2^{3}\right)$ orthogonal table (Table 2). The precipitate containing MAP products were filtered through $0.45 \mu \mathrm{m}$ filter film, then were dried at below $60^{\circ} \mathrm{C}$ before analysis (Ando et al., 1968).

\subsection{Analytical methods}

The suspension $\mathrm{pH}$ was measured using PHS-3C type $\mathrm{pH}$ meter (Shanghai Hongyi Co. Ltd., China). The $\mathrm{NH}_{4}{ }^{+}-$ $\mathrm{N}$ and $\mathrm{PO}_{4}{ }^{3-}-\mathrm{P}$ concentrations were analyzed according to the Standard Methods (APHA, 1995). A definite amount of $0.1500 \mathrm{~g}$ drying precipitate harvested from tests was weighed accurately and dissolved completely in $500 \mathrm{ml}$ $1+19(V+V)$ hydrochloric acid (i.e., its concentration was about $0.6 \mathrm{~mol} / \mathrm{L}$ ), respectively. Total $\mathrm{P}$ and metals including $\mathrm{K}, \mathrm{Na}, \mathrm{Ca}, \mathrm{Ni}, \mathrm{Mn}$, and $\mathrm{Mg}$ of the harvested precipitate solutions were analyzed by ICP (OES Optima 5300DV, America PE, USA), and total N by TNM-1 (TOCVCPN TN unit, Shimadzu, Japan). The minerals in the precipitates were identified by X-ray Diffraction (XRD, $\mathrm{D} / \max -\mathrm{Rb}$, Japan).

\section{Results and discussion}

\subsection{Urea hydrolysis at different initial pH (S\#1)}

Alkaline condition prefers struvite crystallization. If urea hydrolysis could be achieved at alkaline conditions, no further $\mathrm{pH}$ adjustment might be needed in the subsequent MAP precipitation process. A steady $\mathrm{pH}$ range of 8.9-9.3 could be reached following $84 \mathrm{~h}$ of urea hydrolysis 
Table 2 Factor and its level in orthogonal design for magnesium ammonium phosphate (MAP) precipitation

\begin{tabular}{lllllll}
\hline Level & \multicolumn{5}{c}{ Factor } \\
\cline { 2 - 7 } & $\mathrm{pH}$ & $\mathrm{Mg}: \mathrm{N}(\mathrm{mol}: \mathrm{mol})$ & $\mathrm{P}: \mathrm{N}(\mathrm{mol}: \mathrm{mol})$ & $\theta(\mathrm{h})$ & $v(\mathrm{r} / \mathrm{min})$ & $t(\mathrm{~min})$ \\
\hline 1 & 8.0 & $1.0: 1$ & $1.0: 1$ & 1 & 60 & 120 \\
2 & 8.5 & $1.1: 1$ & $1.05: 1$ & 2 & & 30 \\
3 & 9.5 & $1.2: 1$ & $1.1: 1$ & 3 & & \\
4 & 10.0 & $1.3: 1$ & $1.15: 1$ & 4 & & \\
\hline
\end{tabular}

$\theta$ : precipitation time; $v$ : mixing speed; $t$ : reaction time.

in all tested cases (Fig.1a). The $\mathrm{NH}_{4}{ }^{+}-\mathrm{N}$ concentration first increased but slowly decreased with hydrolysis in these tests (Fig.1b). For fresh urine (control), the $\mathrm{pH}$ became steady after $60 \mathrm{~h}$ while the highest $\mathrm{NH}_{4}{ }^{+}-\mathrm{N}$ concentration appeared at $72 \mathrm{~h}$ of test. The samples at higher initial $\mathrm{pH}$ needed longer hydrolysis time to reach steady state at higher $\mathrm{NH}_{4}{ }^{+}-\mathrm{N}$ concentration compared with the control. For example, at an initial $\mathrm{pH}$ of 8 or 10 , the highest $\mathrm{NH}_{4}{ }^{+}-\mathrm{N}$ concentration appeared at a hydrolysis time of 96 or $108 \mathrm{~h}$, respectively. The reason of higher $\mathrm{pH}$ affecting the urea hydrolysis obviously was that the urease activity was very low at higher $\mathrm{pH}$, because the urea hydrolyzing bacteria died more quickly at $\mathrm{pH} 8.9$ and 10.5 than at pH 6.0 (Höglund et al., 1998). Restated, the alkalescence hydrolysis effects on separated human urine were insignificant.

Both ammonium and bicarbonate ions are produced during urea hydrolysis (Reaction (2)). Two equilibriums in stale urine exist as follows:

$$
\mathrm{NH}_{4}^{+}+\mathrm{OH}^{-} \longleftrightarrow \mathrm{NH}_{3}(\mathrm{aq})+\mathrm{H}_{2} \mathrm{O} \quad\left(\mathrm{pK}=9.24,25^{\circ} \mathrm{C}\right)
$$

$$
\begin{gathered}
\mathrm{CO}_{3}^{2-}+\mathrm{H}^{+} \longleftrightarrow \mathrm{HCO}_{3}^{-}+\mathrm{H}^{+} \longleftrightarrow \mathrm{H}_{2} \mathrm{CO}_{3} \\
\left(\mathrm{p} K_{1}=10.33, \mathrm{p} K_{2}=6.35,25^{\circ} \mathrm{C}\right)
\end{gathered}
$$

further, phosphate ions in stale urine could achieve chemical equilibrium as follows:

$$
\begin{gathered}
\mathrm{PO}_{4}^{3-}+\mathrm{H}^{+} \longleftrightarrow \mathrm{HPO}_{4}^{2-}+\mathrm{H}^{+} \longleftrightarrow \mathrm{H}_{2} \mathrm{PO}_{4}^{-} \\
\left(\mathrm{p} K_{1}=12.35, \mathrm{p} K_{2}=7.21,25^{\circ} \mathrm{C}\right)
\end{gathered}
$$

thus, the stale urine has strong buffer capacity to the added alkali or acid. However, the fresh urine has weaker buffer action than stale urine owing to its lower concentrations of ammonium, bicarbonate, and phosphate ions (Fig.1a). Hellström et al. (1999) also noted a final pH of 9.0 with an initial $\mathrm{pH}$ of urine adjusted to less than 2.0. The final $\mathrm{pH}$ of source-separated urine would be all around 9.0 regardless of initial suspension $\mathrm{pH}$ owing to the strong buffer effects on the stale urine.

\subsection{Urea hydrolysis with different volumetric ratio of stale to fresh urine}

Source-separated urine was generally collected in a tank and urea was decomposed during storage. When fresh urine was mixed with stale urine, urea hydrolysis would occur with the function of the available urease in a short time (Mobley and Hausinger, 1989). The $\mathrm{pH}, \mathrm{NH}_{4}{ }^{+}-\mathrm{N}$ and $\mathrm{PO}_{4}{ }^{3-}-\mathrm{P}$ changes following urea hydrolysis at different volumetric ratios of stale to fresh urines as illustrated in Fig.2.

Urea hydrolysis was enhanced in mixed urines (Fig.2) compared with those with fresh urines. For instance, with fresh urine $\left(0 \%\right.$, volumetric ratio), the $\mathrm{pH}$ and $\mathrm{NH}_{4}{ }^{+}-\mathrm{N}$ concentration became steady at 72 and $84 \mathrm{~h}$, respectively. At a volumetric ratio of $20 \%$, the corresponding time became $36 \mathrm{~h}$ (Figs.2a and 2b). It means that the presence of residual stale urine in the collecting tank significantly decreases the hydrolysis time of urea. The hydrolysis time of urea by adding stale urine was longer than that by adding urease which only needed 1.5 h (Kabdaşli et al., 2006), but the former was more economical and convenient in practice.

During the hydrolysis experiment, the $\mathrm{PO}_{4}{ }^{3-}-\mathrm{P}$ concentration rapidly decreased at $12 \mathrm{~h}$ and was steady with the exception of the control experiment $(0 \%, \mathrm{SU})$. The changes

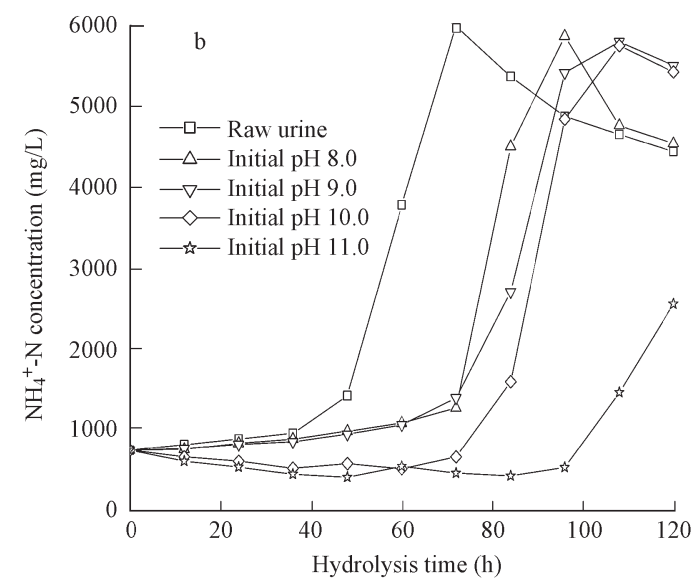

Fig. 1 Urine $\mathrm{pH}$ (a) and $\mathrm{NH}_{4}{ }^{+}-\mathrm{N}$ concentration (b) change with urea hydrolysis time at different initial $\mathrm{pH}$. 

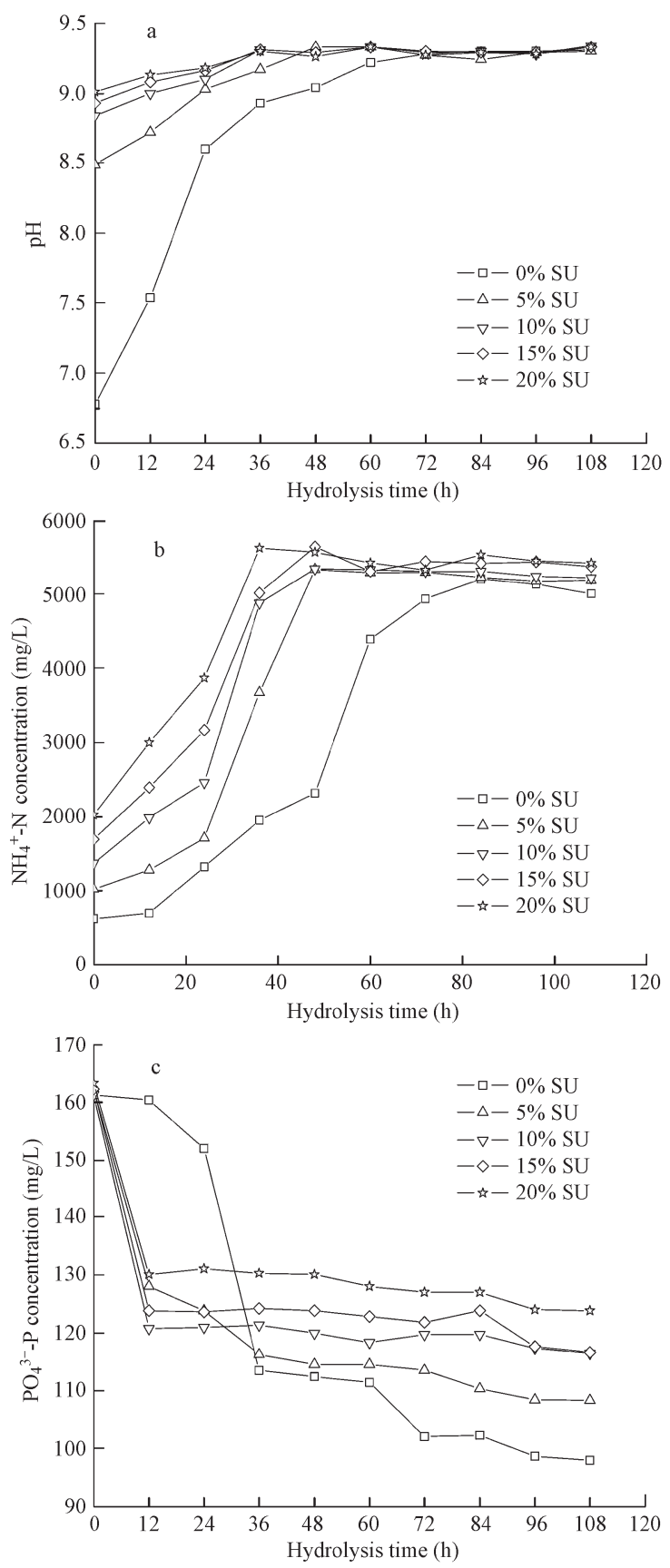

Fig. 2 Urine $\mathrm{pH}(\mathrm{a}), \mathrm{NH}_{4}{ }^{+}-\mathrm{N}$ concentration (b), and $\mathrm{PO}_{4}{ }^{3-}-\mathrm{P}$ concentration (c) change with hydrolysis time at different volumetric ratio of stale urine $(\mathrm{SU})$.

in $\mathrm{PO}_{4}{ }^{3-}-\mathrm{P}$ concentration following hydrolysis was smaller than those in $\mathrm{NH}_{4}{ }^{+}-\mathrm{N}$ concentration. Udert et al. (2003c) noted that MAP and hydroxyapatite (HAP) are the sole minerals in undiluted urine. The HAP reaction can be stated as follows:

$$
\begin{gathered}
3 \mathrm{PO}_{4}^{3-}+5 \mathrm{Ca}^{2+}+\mathrm{OH}^{-} \longleftrightarrow \mathrm{Ca}_{5}(\mathrm{OH})\left(\mathrm{PO}_{4}\right)_{3} \\
\left(\mathrm{p} K \mathrm{sp}=57.5,25^{\circ} \mathrm{C}\right)
\end{gathered}
$$

restated, both MAP and HAP reactions would mainly take place in alkaline condition, particularly Reaction (1) occurs at $\mathrm{pH}>8$ for satisfactory MAP precipitation ( $\mathrm{Li}$ and Zhao, 2003; Adnan et al., 2003). In urine, both $\mathrm{Ca}^{2+}$ and $\mathrm{Mg}^{2+}$ are deficient compared to $\mathrm{NH}_{4}{ }^{+}-\mathrm{N}$ and $\mathrm{PO}_{4}{ }^{3-}$ according to Reactions (1) and (6) (Udert et al., 2003c; Katarzyna and Grietje, 2006). Therefore, when the $\mathrm{pH}$ was increased to 8.0 or above, the $\mathrm{PO}_{4}{ }^{3-}-\mathrm{P}$ concentration in urine decreased sharply by MAP and HAP precipitation, and then became steady due to the deficiency of $\mathrm{Ca}^{2+}$ and $\mathrm{Mg}^{2+}$ (Fig.2c).

\subsection{Urea hydrolysis at different temperatures}

High temperature prefers urea hydrolysis (Fig.3). For instance, at $30^{\circ} \mathrm{C}$ the highest $\mathrm{NH}_{4}{ }^{+}-\mathrm{N}$ concentration could be reached at $36 \mathrm{~h}$, meanwhile, the $\mathrm{NH}_{4}{ }^{+}-\mathrm{N}$ concentration was only $40 \%$ or less of the highest value at temperature $<$ $15^{\circ} \mathrm{C}$ (Fig. $3 \mathrm{~b}$ ). At temperature $>20^{\circ} \mathrm{C}$, the corresponding
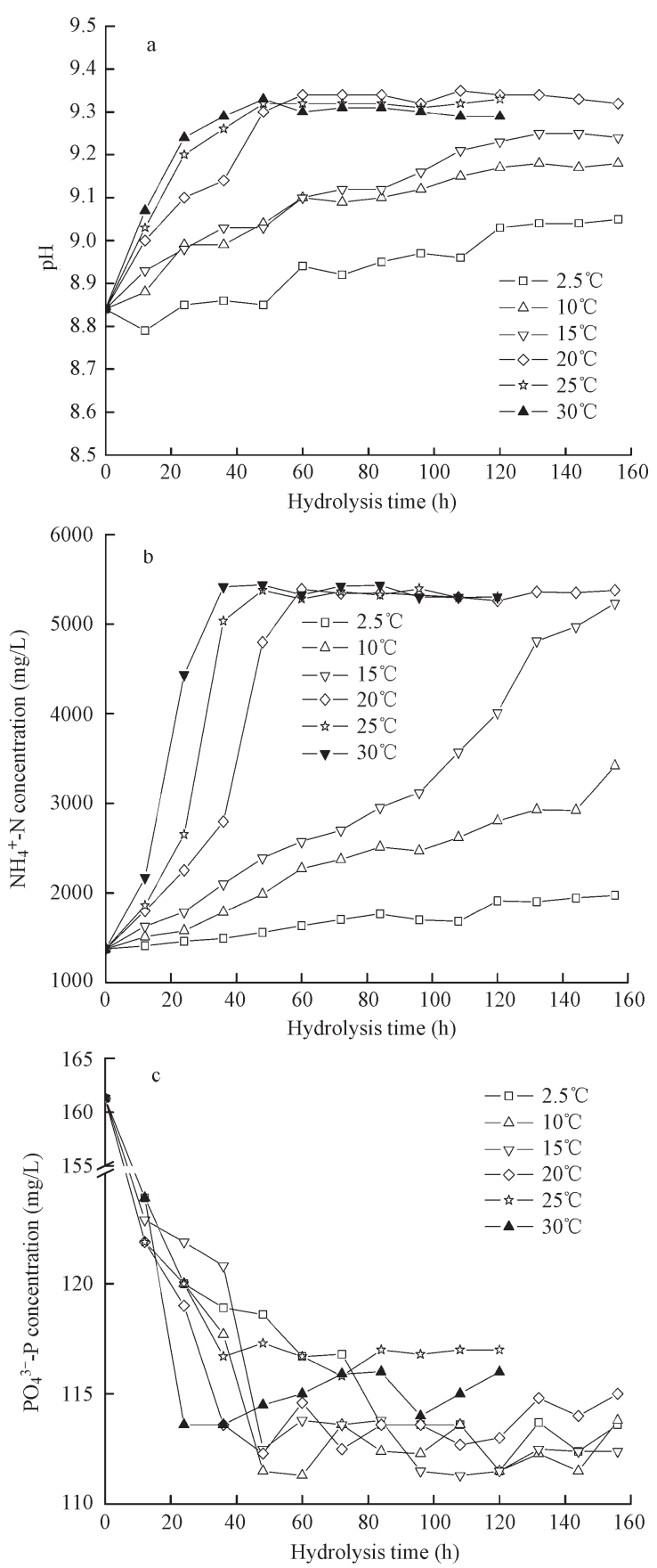

Fig. 3 Urine $\mathrm{pH}(\mathrm{a}), \mathrm{NH}_{4}{ }^{+}-\mathrm{N}$ concentration (b), and $\mathrm{PO}_{4}{ }^{3-}-\mathrm{P}$ concentration (c) change with hydrolysis time at different temperature. 
urea hydrolysis time would not be decreased further. In other words, the urea could be hydrolyzed within $60 \mathrm{~h}$ when the volumetric ratio of stale urine to fresh urine exceeded $10 \%$ at temperature $>20^{\circ} \mathrm{C}$. The $\mathrm{PO}_{4}{ }^{3-}-\mathrm{P}$ concentrations rapidly decreased at $12 \mathrm{~h}$ of hydrolysis when the temperature was above $15^{\circ} \mathrm{C}$, while at temperature $<$ $15^{\circ} \mathrm{C}$, the change rates in $\mathrm{PO}_{4}{ }^{3-}-\mathrm{P}$ concentration declined slowly, and reached plateau values at $>48 \mathrm{~h}$ (Fig.3c).

Initial suspension $\mathrm{pH}$ affected the highest $\mathrm{NH}_{4}{ }^{+}-\mathrm{N}$ concentration achievable in hydrolysis. However, the ammonia loss owing to evaporation should be considered in interpreting these data since the tests were conducted in open beakers (Fig.1b). Sealing should be applied in the sourceseparated urine collection tank to minimize ammonia loss (Hanæus et al., 1997).

In the experiments, the hydrolysis time and the average $\mathrm{pH}$ and $\mathrm{PO}_{4}{ }^{3-}-\mathrm{P}$ concentration of fresh urine were 6.76.8 and 161-171 mg/L, respectively, slightly different from those reported in the published report (Udert et al., 2003c). These differences may be yielded by the fact that the present study collected fresh urine using barrels without pre-disinfection, for simulating practical urinal flush, thus certain urease pollution may occur.

In the present tests, suspension $\mathrm{pH}$ closely corresponded to the noted $\mathrm{NH}_{4}{ }^{+}-\mathrm{N}$ concentration. Hence, the suspension $\mathrm{pH}$, which was easily measured during experiments, may be used as an indicator to the extent of urea hydrolysis if the long-lasting period with slow hydrolysis was disregarded (comparing Fig.1a with Fig.1b, Fig.2a with Fig.2b, and Fig.3a with Fig.3b).

\subsection{MAP precipitation tests}

The orthogonal table $\mathrm{L}_{16}\left(4^{4} \times 2^{3}\right)$ was designed and 16 groups of experiments were conducted with the results shown in Table 3. The molar ratio of $\mathrm{Mg}: \mathrm{N}$ was the most significant, while the mixing speed was the least factor affecting the $\mathrm{NH}_{4}{ }^{+}-\mathrm{N}$ and $\mathrm{PO}_{4}{ }^{3-}-\mathrm{P}$ recovery rates. The best results amongst the sixteenth experiments yielded residual $\mathrm{NH}_{4}{ }^{+}-\mathrm{N}$ and $\mathrm{PO}_{4}{ }^{3-}-\mathrm{P}$ concentrations of 87.5 and $8.34 \mathrm{mg} / \mathrm{L}$, respectively. Taking the economic aspect into consideration as well, the optimum reaction $\mathrm{pH}, \mathrm{Mg}: \mathrm{N}$ (mol:mol), P:N (mol:mol), $\theta, v$, and $t$ were 8.5, (1.2-1.3):1, $1: 1,3 \mathrm{~h}, 120 \mathrm{r} / \mathrm{min}$, and $15 \mathrm{~min}$, respectively.

To validate the results of the orthogonal experiments, two further tests with respective $\mathrm{Mg}: \mathrm{N}: \mathrm{P}$ (mol:mol:mol) of 1.2:1:1 and 1.3:1:1 were conducted with all other conditions fixed at those determined at optimum. The residual $\mathrm{NH}_{4}{ }^{+}-\mathrm{N}$ and $\mathrm{PO}_{4}{ }^{3-}-\mathrm{P}$ concentrations were 251 and $25 \mathrm{mg} / \mathrm{L}(1.2: 1: 1)$, and 318 and $9.0 \mathrm{mg} / \mathrm{L}(1.3: 1: 1)$, respectively. Hence, the MAP precipitation could recover most $\mathrm{NH}_{4}{ }^{+}-\mathrm{N}$ and $\mathrm{PO}_{4}{ }^{3-}-\mathrm{P}$ from stale human urine, and the $\mathrm{NH}_{4}{ }^{+}-\mathrm{N}$ and $\mathrm{PO}_{4}{ }^{3-}-\mathrm{P}$ recovery efficiency were above $95 \%$ and $85 \%$, respectively. Moreover, the two precipitates with the presence of trace calcium, potassium and sodium collected revealed similar chemical structure to pure MAP (Table 4). The XRD analysis also confirmed that the precipitates were mostly pure $\mathrm{MgNH}_{4} \mathrm{PO}_{4} \cdot 6 \mathrm{H}_{2} \mathrm{O}$ (Fig.4).

Since the $\mathrm{NH}_{4}{ }^{+}-\mathrm{N}$ concentration is higher than $\mathrm{PO}_{4}{ }^{3-}-\mathrm{P}$ concentration in stale urine, the higher $\mathrm{NH}_{4}{ }^{+}-\mathrm{N}$ removal rate could only be obtained at more chemical doses of $\mathrm{MgCl}_{2} \cdot 6 \mathrm{H}_{2} \mathrm{O}$ and $\mathrm{Na}_{2} \mathrm{HPO}_{4} \cdot 12 \mathrm{H}_{2} \mathrm{O}$ with $\mathrm{NaOH}$. Such an

Table $3 \mathrm{~L}_{16}\left(4^{4} \times 2^{3}\right)$ orthogonal design for MAP precipitation

\begin{tabular}{|c|c|c|c|c|c|c|c|c|}
\hline \multirow[t]{2}{*}{ Sample } & \multicolumn{6}{|c|}{ Factor } & \multicolumn{2}{|c|}{ Residual } \\
\hline & $\mathrm{pH}$ & Mg:N (mol:mol) & P:N (mol:mol) & $\theta(\mathrm{h})$ & $v(\mathrm{r} / \mathrm{min})$ & $t(\min )$ & $\mathrm{NH}_{4}{ }^{+}-\mathrm{N}(\mathrm{mg} / \mathrm{L})$ & $\mathrm{PO}_{4}{ }^{3}-\mathrm{P}(\mathrm{mg} / \mathrm{L})$ \\
\hline 1 & 8.0 & $1.1: 1$ & $1.1: 1$ & 2 & 120 & 15 & 386 & 969.42 \\
\hline 2 & 9.5 & $1.3: 1$ & $1: 1$ & 2 & 60 & 30 & 628 & 15.7 \\
\hline 3 & 8.5 & $1.3: 1$ & $1.1: 1$ & 3 & 120 & 30 & 115 & 13.2 \\
\hline 4 & 10.0 & $1.1: 1$ & $1: 1$ & 3 & 60 & 15 & 438.5 & 11.2 \\
\hline 5 & 8.0 & $1.2: 1$ & $1: 1$ & 4 & 120 & 30 & 546.5 & 6.78 \\
\hline 6 & 9.5 & $1: 1$ & $1.1: 1$ & 4 & 60 & 15 & 614 & $1,779.2$ \\
\hline 7 & 8.5 & $1: 1$ & $1: 1$ & 1 & 120 & 15 & 815 & $1,483.56$ \\
\hline 8 & 10.0 & $1.2: 1$ & $1.1: 1$ & 1 & 60 & 30 & 227 & 16.97 \\
\hline 9 & 8.0 & $1: 1$ & $1.15: 1$ & 3 & 60 & 30 & 791 & $2,434.13$ \\
\hline 10 & 9.5 & $1.2: 1$ & $1.05: 1$ & 3 & 120 & 15 & 245 & 7.2 \\
\hline 11 & 8.5 & $1.2: 1$ & $1.15: 1$ & 2 & 60 & 15 & 68.5 & 147.32 \\
\hline 12 & 10.0 & $1:: 1$ & $1.05: 1$ & 2 & 120 & 30 & 708.5 & $1,560.28$ \\
\hline 13 & 8.0 & $1.3: 1$ & $1.05: 1$ & 1 & 60 & 15 & 489 & 18.76 \\
\hline 14 & 9.5 & $1.1: 1$ & $1.15: 1$ & 1 & 120 & 30 & 261 & $1,686.19$ \\
\hline 15 & 8.5 & $1.1: 1$ & $1.05: 1$ & 4 & 60 & 30 & 323.5 & 560.4 \\
\hline 16 & 10.0 & $1.3: 1$ & $1.15: 1$ & 4 & 120 & 15 & 87.5 & 8.34 \\
\hline \multicolumn{9}{|c|}{ Mean of residual $\mathrm{NH}_{4}{ }^{+}-\mathrm{N}$} \\
\hline KN1 & 553.1 & 732.1 & 607 & 448 & 447.4 & 392.9 & & \\
\hline $\mathrm{KN} 2$ & 330.5 & 352.3 & 441.5 & 447.8 & 395.6 & 450.1 & & \\
\hline KN3 & 437 & 271.8 & 335.5 & 397.4 & & & & \\
\hline KN4 & 365.4 & 329.9 & 302 & 392.9 & & & & \\
\hline $\mathrm{RN}$ & 222.6 & 460.3 & 305 & 55.1 & 51.8 & 57.2 & & \\
\hline \multicolumn{9}{|c|}{ Mean of residual $\mathrm{PO}_{4}{ }^{3-}-\mathrm{P}$} \\
\hline KP1 & 857.3 & 1814.3 & 379.3 & 801.4 & 623 & 553.1 & & \\
\hline KP2 & 551.1 & 806.8 & 536.7 & 673.2 & 716.9 & 786.7 & & \\
\hline KP3 & 872.1 & 44.6 & 694.7 & 616.4 & & & & \\
\hline KP4 & 399.2 & 14 & 1,069 & 588.7 & & & & \\
\hline $\mathrm{RP}$ & 472.9 & $1,800.3$ & 689.7 & 212.7 & 93.9 & 233.6 & & \\
\hline
\end{tabular}



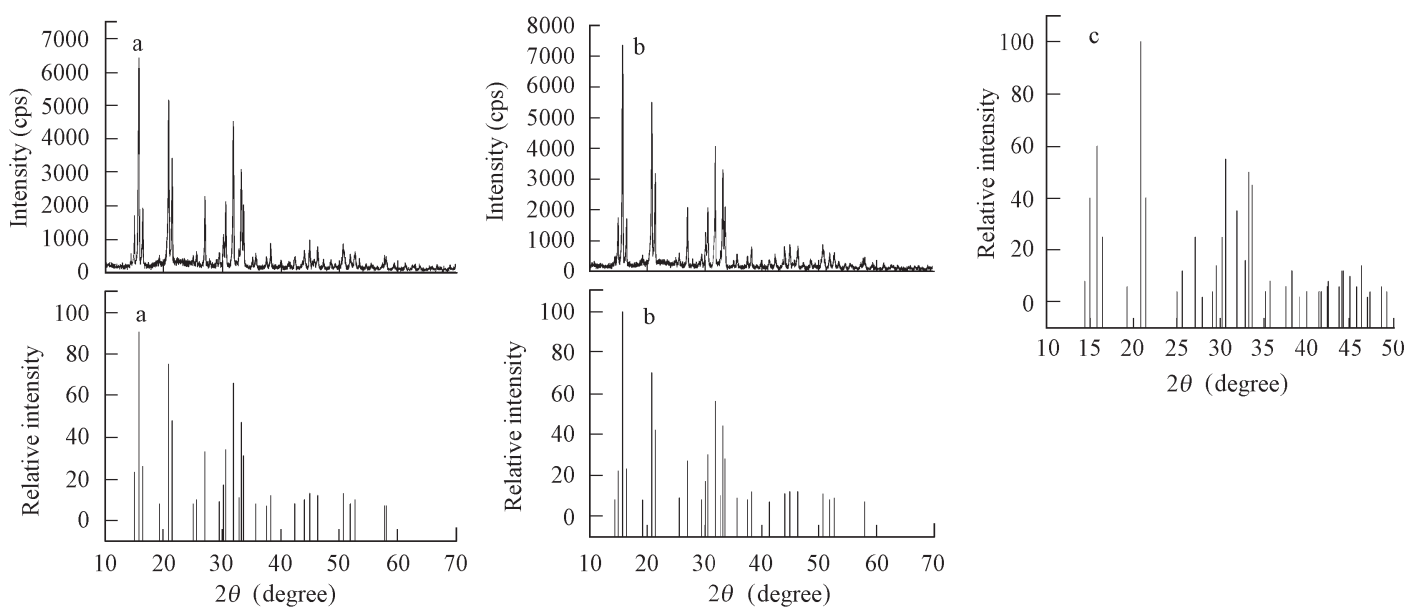

Fig. 4 X-ray diffractographs of the precipitates and pure MAP. (a) precipitate at 1.2:1:1 molar ratio of Mg:N:P; (b) precipitate at 1.3:1:1 molar ratio of $\mathrm{Mg}: \mathrm{N}: \mathrm{P} ;$ (c) standard MAP (ICDC Standard \#15-0762, 1996).

Table 4 Chemical content of pure MAP and precipitates obtained under different mole ratios of Mg:N:P (\%)

\begin{tabular}{lllllllll}
\hline & Sample & $\mathrm{P}$ & $\mathrm{N}$ & $\mathrm{Mg}$ & $\mathrm{Ca}$ & $\mathrm{K}$ & $\mathrm{Ni}$ & $\mathrm{Na}$ \\
\hline \multirow{3}{*}{ Precipitate } & Pure MAP & 12.62 & 5.70 & 9.91 & - & & - & - \\
& $1.2: 1: 1(\mathrm{~mol}: \mathrm{mol}: \mathrm{mol})$ & 13.46 & 4.48 & 8.84 & 0.12 & 0.35 & $<0.001$ & - \\
& $1.3: 1: 1(\mathrm{~mol}: \mathrm{mol}: \mathrm{mol})$ & 13.51 & 4.44 & 8.72 & 0.12 & 0.31 & $<0.001$ & 1.41 \\
\hline
\end{tabular}

occurrence increases operational cost of MAP process. Most phosphorous and part of the $\mathrm{NH}_{4}{ }^{+}-\mathrm{N}$ could be recovered from urine using MAP process without adding with $\mathrm{Na}_{2} \mathrm{HPO}_{4} \cdot 12 \mathrm{H}_{2} \mathrm{O}$ and $\mathrm{NaOH}$, which may be a compromise between high nutrient recovery and low operation cost aspects.

\section{Conclusions}

This study investigated the urea hydrolysis of sourceseparated human urine and following MAP precipitation process to recover nitrogen and phosphorous as a resource. High $\mathrm{pH}$ and low temperature of suspension inhibited urea hydrolysis, while the presence of stale urine assisted this process. Specifically, the urea hydrolysis could be delayed in more than $1 \mathrm{~d}$ at initial $\mathrm{pH}>8$. At temperature $>$ $20^{\circ} \mathrm{C}$ and a volumetric ratio of stale to fresh urine $>10 \%$, the hydrolysis time would be limited in $2 \mathrm{~d}$; while at $<$ $15^{\circ} \mathrm{C}$ the corresponding hydrolysis time would exceed 6.5 $\mathrm{d}(156 \mathrm{~h})$.

The $\mathrm{pH}$ of urine increased and stabilized at around 9.0 following hydrolysis, which may be used as an indicator to the extent of urea hydrolysis. The $\mathrm{PO}_{4}{ }^{3-}$-P concentration was rapidly decreased at $\mathrm{pH}>8$, but would reach steady state at deficient supply of $\mathrm{Ca}^{2+}$ and $\mathrm{Mg}^{2+}$ ions.

The recovery efficiency of $\mathrm{NH}_{4}{ }^{+}-\mathrm{N}$ and $\mathrm{PO}_{4}{ }^{3-}-\mathrm{P}$ using MAP process from stale urine could reach above $95 \%$ and $85 \%$, respectively, at the optimal operational conditions identified as follows: molar ratio of $\mathrm{Mg}^{2+}: \mathrm{NH}_{4}{ }^{+}-$ $\mathrm{N}: \mathrm{PO}_{4}{ }^{3-}-\mathrm{P}$ of (1.2-1.3):1:1, $\mathrm{pH} 8.5$, precipitation time of $3.0 \mathrm{~h}$, mixing speed of $120 \mathrm{r} / \mathrm{min}$, and reaction time of 15 min. The chemical structures of the MAP precipitates were similar to those of the pure MAP crystals, which could be used as a slow-release fertilizer.

\section{Acknowledgements}

This work was supported by the Program for Changjiang Scholars and Innovative Research Team in University (PCSIRT), the Ministry of Education (No. IRT0424).

\section{References}

Adnan A, Mavinic D S, Koch F A, 2003. Pilot-scale study of phosphorus recovery through struvite crystallizationexamining the process feasibility. J Environ Eng Sci, 2(5): $315-324$.

Ando J, Akiyama T, Morita M, 1968. Magnesium ammonium phosphate, related salts and their behavior in compound fertilizers. Bull Chem Soc Jpn, 41: 1716-1723.

APHA, 1995. Standard Methods for the Examination of Water and Wastewater (19th ed.). Washington DC, USA: American Public Health Association.

Ban Z, Dave G, 2004. Laboratory studies on recovery of N and $\mathrm{P}$ from human urine through struvite crystallisation and zeolite adsorption. Environ Technol, 25(1): 111-121.

Basakcilardan-Kabakci S, Ipekoglu A N, Talini I, 2007. Recovery of ammonia from human urine by stripping and absorption. Environ Eng Sci, 24(5): 615-624.

Fittschen I, Hahn H H, 1998. Characterization of the municipal wastewater and a preliminary comparison with liquid cattle excretion. Water Sci Technol, 38(6): 9-16.

Hanæus J, Hellström D, Johansson E, 1997. A study of a urine separation system in an ecological village in northern Sweden. Water Sci Technol, 35(9): 153-160.

Hellström D, Johansson E, Grennberg K, 1999. Storage of human urine: Acidification as method to inhibit decomposition of urea. Ecol Eng, 12: 253-269.

Höglund C, Stenström T A, Jönsson H, Sundin A, 1998. Evaluation of faecal contamination and microbial die-off in urine separating systems. Water Sci Technol, 38(6): 17-25.

ICDD (International Center for Diffraction Data), 1996. Ammo- 
nia magnesium phosphate hydrate (Standard \#15-0762). A Computer Database.

Jönsson H, Stenström T A, Svensson J, Sundin A, 1997. Source separated urine-nutrient and heavy metal content, water saving and faecal contamination. Water Sci Technol, 35(9): $145-152$.

Kabdaşli I, Tünay O, Íşlek Ç, Erdinç E, Hüskalar S, Tatlı M B, 2006. Nitrogen recovery by urea hydrolysis and struvite precipitation from anthropogenic urine. Water Sci Technol, 53(12): 305-312.

Katarzyna K R, Grietje Z, 2006. Anaerobic treatment in decentralized and source-separation-based sanitation concepts. Rev in Environ Sci and Bio/Technol, 5: 115-139.

Kirchmann H, Pettersson S, 1995. Human urine-chemical composition and fertilizer use efficiency. Fertilizer Res, 40(2): $149-154$.

Larsen T A, Gujer W, 1996. Separated management of anthropogenic nutrient solutions (human urine). Water Sci Technol, 34(3-4): 87-94.

Larsen T A, Udert K M, 1999. Urine separation - a way of closing the nutrient cycles. Wasser und Boden, 51(11): 6-9.

Larsen T A, Peters I, Alder A, Eggen R, Maurer M, Muncke J, 2001. Re-engineering the toilet for sustainable wastewater management. Environ Sci Technol, 35(9): 192A-197A.

Lind B B, Ban Z, Byden S, 2000. Nutrient recovery from human urine by struvite crystallization with ammonia adsorption on zeolite and wollastonite. Bioresource Technol, 73(2): 169-174.

Lind B B, Ban Z, Byden S, 2001. Volume reduction and concentration of nutrients in human urine. Ecol Eng, 16: 561-566.
Li X Z, Zhao Q L, 2003. Recovery of ammonium-nitrogen from landfill leachate as a multi-nutrient fertilizer. Ecol Eng, 20(2): 171-181.

Maurer M, Schwegler P, Larsen T A, 2003. Nutrients in urine: energetic aspects of removal and recovery. Water Sci Technol, 48(1): 37-46.

Mobley H L T, Hausinger R P, 1989. Microbial ureases: significance, regulation, and molecular characterization. Microbiol Rev, 53(1): 85-108.

Pahl-Wosti C, Schönborn A, Willi J, Larsen T A, 2003. Investigating consumer attitudes towards the new technology of urine separation. Water Sci Technol, 48(1): 57-65.

Pronk W, Palmquist H, Biebow M, Boller M, 2006. Nanofiltration for the separation of pharmaceuticals from nutrients in source-separated urine. Water Res, 40(7): 1405-1412.

Udert K M, Larsen T A, Biebow M, Gujer W, 2003a. Urea hydrolysis and precipitation dynamics in a urine-collecting system. Water Res, 37(11): 2571-2582.

Udert K M, Fux C, Münster M, Larsen T A, Siegrist H, Gujer W, 2003b. Nitrification and autotrophic denitrification of source-separated urine. Water Sci Technol, 48(1): 119-130.

Udert K M, Larsen T A, Gujer W, 2003c. Estimating the precipitation potential in urine-collecting systems. Water Res, 37(11): 2667-2677.

Wilsenach J A, Van Loosdrecht M C M, 2003. Impact of separate urine collection on wastewater treatment systems. Environ Sci Technol, 48(1): 103-110.

Wilsenach J A, Van Loosdrecht M C M, 2004. Effects of separate urine collection on advanced nutrient removal processes. Environ Sci Technol, 38(4): 1208-1215. 